\title{
Furan ring transformation as a key stage in pyrrolopyrazine framework synthesis
}

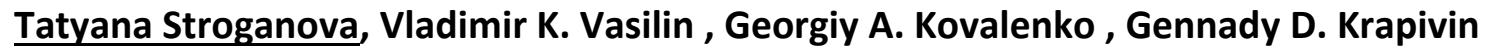 \\ Kuban State Technological University, Department of Bioorganic Chemistry and Technical \\ Microbiology, \\ Moskovskaya st. 2, Krasnodar 350072, Russian Federation; E-mail: tatka_s@mail.ru
}

\section{Introduction}

For many years benzimidazoles are of interest for medicinal chemistry. Among them compounds having antihistamine [1] and antibacterial [1,2] activity are found. Benzimidazole derivatives exhibit cytostatic [1], anesthetic, hypotensive and antipyretic activities [3]. So synthesis of novel benzimidazole derivatives, including annelated polycyclic systems, is very important.

\section{Results and discussion}

In continuation of our previous investigations on usage of furan compounds for various fused heterocyclic systems synthesis we studied a furan ring recyclization in 1-(5-alkylfuryl2)benzimidazoles. Earlier we have used similar compounds bearing methyl group at position 2 of benzimidazole ring for 1-(pyrrol-2-ylmethyl)benzimidazole synthesis [4] (Scheme 1). The method included two stages: furan ring opening to obtain 1,4-diketone unit and $\mathrm{N}$-substituted pyrrole ring formation via an interaction of the diketone with primary amines. We showed that an application of various primary amines (aliphatic or aromatic) allowed preparing a wide range of pyrrolylmethylbenzimidazoles which were hard-to-reach by another ways.

Scheme 1

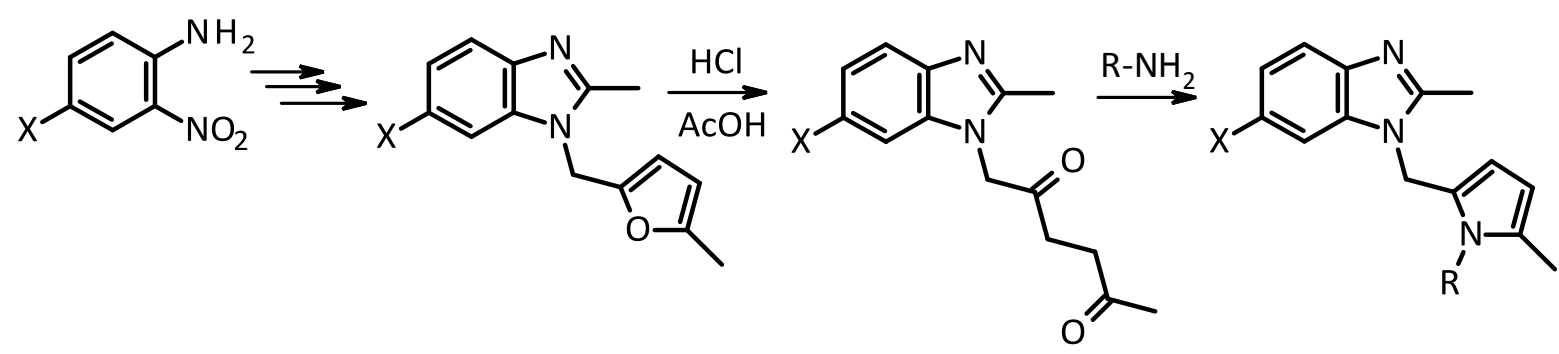

Now we present an original approach to pyrrolo[1',2':4,5]pyrazino[1,2-a]benzimidazole derivatives based on a recyclization of furan ring. Earlier we have utilized similar strategy for fused pyrrolo[1,2-a][1,4]diazepines [5] and pyrrolo[1,2-a][1,4]diazocines syntheses [6]. The unique feature of both transformations was a simultaneous formation of pyrrole and diazepine (or diazocine) ring. As described earlier for pyrrolodiazepines [5], the key stage of pyrrolopyrazinobenzimidazole framework synthesis is an intermediate A formation (Scheme 2). 
<smiles>[X]c1ccc2c(c1)nc1n2Cc2ccc([R])n2C1</smiles>

2<smiles>[R]C(=O)CCC(=O)Cn1c(CN)nc2ccccc21</smiles>

A<smiles>[R]c1ccc(Cn2c(CCl)nc3ccccc32)o1</smiles>

The intermediate A can be prepared from benzimidazoles 1 via two stages: an amino group introduction and formation of 1,4-diketone unit from furan ring (Scheme 3).

Scheme 3<smiles>[X]c1ccc2c(c1)nc(CCl)n2Cc1ccc([R])o1</smiles>

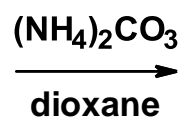<smiles>[X]c1ccc2c(c1)nc(CN)n2Cc1ccc([R])o1</smiles><smiles>CC1(C(=O)O)CCCCC1</smiles>

$\stackrel{\mathrm{HCl} / \mathrm{AcOH}}{\longrightarrow}$<smiles>[R]C(=O)CCC(=O)Cn1c(CCl)nc2cc([X])ccc21</smiles>

$\left(\mathrm{NH}_{4}\right)_{2} \mathrm{CO}_{3}$ dioxane

The first path includes an acid-catalyzed transformation of furan ring in 2-aminomethyl1-(5-alkylfuryl-2)methylbenzimidazoles. The reaction proceeds as a domino-process and lead to new heterocyclic system - pyrrolo[1',2':4,5]pyrazino[1,2-a]benzimidazole - via simultaneous pyrrole and pyrazine ring closure. The key stage of the reaction is an intramolecular furan ring recyclization (Scheme 4).

Scheme 4<smiles>[X]c1ccc(N)c([N+](=O)[O-])c1</smiles><smiles>C=CC</smiles><smiles>[X]c1ccc(NC(=O)CCl)c(N)c1</smiles><smiles>[R]c1ccc(C=O)o1</smiles><smiles>[R]c1ccc(CNc2ccc([Y])o2)c(NC(=O)CCl)c1</smiles>

$\mathrm{AcOH}$<smiles>[X]c1ccc2nc(CCl)n(Cc3ccc([R])o3)c2c1</smiles>
$\frac{\left(\mathrm{NH}_{4}\right)_{2} \mathrm{CO}_{3}}{\mathrm{NH} 3, \mathrm{EtOH}}$<smiles>[X]c1ccc2nc(CN)n(Cc3ccc([R])o3)c2c1</smiles>

$\mathrm{HCl} / \mathrm{ACOH}$<smiles>[X]c1ccc2nc3n(c2c1)Cc1ccc([R])n1C3</smiles>

$\mathrm{X}=\mathrm{H}, \mathrm{CH}_{3}, \mathrm{Cl} ; \mathrm{R}=\mathrm{CH}_{3}, \mathrm{C}_{2} \mathrm{H}_{5}$ 
According the second path firstly a diketone fragment was prepared from furan ring under the action of $\mathrm{HCl} / \mathrm{AcOH}$ mixture. Treating the obtained compounds with $\mathrm{NH}_{4} \mathrm{HCO}_{3}$ in $\mathrm{NH}_{4} \mathrm{OH}$ resulted in desired pyrrolo[1',2':4,5]pyrazino[1,2-a] benzimidazoles as main products.

Structures of all prepared compounds are determined using ${ }^{1} \mathrm{H}$ and ${ }^{13} \mathrm{C} N M R$ spectroscopy, mass-spectrometry and elemental analysis data.

The study was supported by The Ministry of Education and Science of Russian Federation, project 2515.

\section{References}

[1] A. A. Spasov, I. N. Yozhitsa, L. I.Bugaeva, V. A. Anisimova, Pharm. Chem. J. 33 (1999), 232-243.

[2] S. O. Podunavac-Kuzmanovic, D. M. Cvetkovic, J. Serb. Chem. Soc. 72 (2007), 459-466.

[3] V. K. Pandey, M. Upadhyay, M. Upadhyay, V. D. Gupta, M. Tandon, Acta Pharm. (Zagreb, Croatia). 55 (2005), 47.

[4] T. A. Stroganova, V. M. Redkin, G. A. Kovalenko, V. K. Vasilin, G. D. Krapivin, Chemistry of Heterocyclic Compounds. 49 (2013), 1264-1273.

[5] T. Stroganova, A. Butin, V. Vasilin, T. Nevolina, G. Krapivin, Synlett. (2007), 1106-1108.

[6] T. A. Stroganova, V. K. Vasilin, G. D. Krapivin Synlett. 27 (2016), 1569-1571. 